\title{
福祉医 療施設考
}

\author{
小 野 啓 郎*
}

\section{はじめに}

リハビリテーション医療に携る人達の間に「壁に突き 当った」といら気持あるいは諦観のよらなものが強まっ ていると聞いたことがある。たしかにどのよらな心身障 害にも，PT, OTが立ち向っていく無鉄砲な姿は知識や 経験と逆比例して消えつつあるのだろう．たしかに少数 の専門医と限られたリ八技術者が何とかできる心身障害 などというのは障害のうちに入らないのかもしれない。 ではどうすればよいのだろう。もっと専門職員を，もっ とリハビリテーションセンターをといら願いは誰しも抱 くところであろうが，それで果して障害者を今の社会へ 本当に復帰させらるのかといら懷疑が関係者達の心の奥 底には拭いきれないのではあるまいか，その籍りのよう なものががむしゃらの PT，OT でなくしてしまうのだ
ろう。

財政をかたさけるる程の医療の公費負担制度や一大リ八 ビリテーションセンター建設は, 地方自治体にとっても それなりの業績になったと同時にいささか苦みのある貴 重な教訓を残したに相違ない．選挙公約の実現が必ずし も地域住民に真の利益をもたらさない事例は決して少な くない，施策が現在・未来にわたってどうかといら科学 的な吟味がなされることは，日本でははなはだまれだか らである。一種の流行のように拡がった福祉センター, リハセンター建設は今や十分な吟味をらける時期にさし かかっているのではあるまいか。リ八職員の間からこそ 貴重な批判がわき，本当に機能的でどんな時代にも住民 の多面的な要望にこたえられる福祉医療の在り方が提案 されるべきだと思う．現在のところこの種の提案は，か 兌って自治体の福祉担当職員や社会学者の間で提唱され

表 1 各機関による福祉指標（社会指標）体系の主要因の比較

\begin{tabular}{|c|c|c|c|c|c|c|c|}
\hline & & O.E.C.D. & 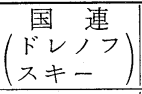 & $\begin{array}{c}\text { アメリカ } \\
\left(\begin{array}{l}\text { 社会報告の } \\
\text { ために }\end{array}\right)\end{array}$ & $\begin{array}{l}\text { 同盟勤労者 } \\
\text { 福 祉 指 標 }\end{array}$ & $\begin{array}{l}\text { 東京都の } \\
\text { 福祉指標 }\end{array}$ & $\begin{array}{l}\text { 国民生活審 } \\
\text { 議会 }\end{array}$ \\
\hline $\begin{array}{c}\text { 基 } \\
\text { 礎 } \\
\stackrel{\text { 的 }}{=} \\
\text { l } \\
\text { ド }\end{array}$ & $\begin{array}{l}\text { (1)所得と消費 } \\
\text { (2)安全・安定 } \\
\text { (3)健 康 }\end{array}$ & $\begin{array}{l}\text { 財貨・サー- } \\
\text { ビスの支配 } \\
\text { 公共の安全 } \\
\text { 之正義 } \\
\text { 健 康. }\end{array}$ & $\begin{array}{l}\text { 栄 養 } \\
\text { 安 全 } \\
\text { 健 康 }\end{array}$ & $\begin{array}{l}\text { 所得と貧困 } \\
\text { 公共の秩序と } \\
\text { 安全 } \\
\text { 健康と疾病 }\end{array}$ & $\begin{array}{l}\text { 所得おょび資産の } \\
\text { 水準・安定・分配 } \\
\text { 人命尊重度 } \\
\text { 保健・衛生 }\end{array}$ & $\begin{array}{l}\text { 所得 - 消費 } \\
\text { 安 全 } \\
\text { 健 康 }\end{array}$ & $\begin{array}{l}\left(\begin{array}{l}\text { 財貨・サー支配 } \\
\text { ビス公共の安全 }\end{array}\right. \\
\text { 健 康 }\end{array}$ \\
\hline $\begin{array}{r}\text { 環 } \\
\text { 境 } \\
\text { 上 } \\
\text { II } \\
\text { = } \\
1 \\
\text { ド }\end{array}$ & $\begin{array}{l}\text { (4)自然環境の保全 } \\
\text { (自然との調和) } \\
\text { (5)居 住 環 境 } \\
\text { (6)労 働 環 境 }\end{array}$ & $\begin{array}{l}\} \text { 物的環境 } \\
\text { 労働之雇用 }\end{array}$ & $\begin{array}{l}\text { 環 境 } \\
\text { 居 住 }\end{array}$ & 物 的 環 境 & $\begin{array}{l}\text { 生活 } \\
\text { 環境 } \\
\text { 環境破壊 } \\
\text { 居住環境 }\end{array}$ & $\begin{array}{l}\text { 自然環 境 } \\
\text { 集堹 活 } \\
\text { 通信 } \\
\text { 労 働 }\end{array}$ & $\begin{array}{l}\text { 物 的 環 境 } \\
\text { (労 働) }\end{array}$ \\
\hline III $\begin{array}{c}\text { 高 } \\
\text { 次 } \\
= \\
1 \\
\text { ド }\end{array}$ & $\begin{array}{l}\text { (7)教育・文化 } \\
\text { (8)余 暇 } \\
\text { (9)参加と連帯 }\end{array}$ & $\begin{array}{l}\text { 学 習 } \\
\text { 余㗇と時間 } \\
\text { コミュニテ } \\
\text { ィ }\end{array}$ & $\begin{array}{l}\text { 教 育 } \\
\text { 余 㗇 }\end{array}$ & $\begin{array}{l}\text { 学習・科学・ } \\
\text { 芸術 } \\
\text { 社会的流動性 } \\
\text { - 参加と疎外 }\end{array}$ & $\begin{array}{l}\text { 教育・文化・情報 } \\
\text { 余 倨 } \\
\text { 創造・参加 }\end{array}$ & $\begin{array}{l}\text { 教 育 } \\
\text { 余 暇 } \\
\text { 連 带 }\end{array}$ & $\begin{array}{l}\text { 教 育 } \\
\text { 余 睱 } \\
\text { コミュニティ } \\
\text { と生活の質 }\end{array}$ \\
\hline
\end{tabular}

(「福祉サービス水準の測定に関する調査研究」より)

\footnotetext{
$*$ 大阪大学医学部整形外科
} 
表 2 览童福祉指標

\begin{tabular}{|c|c|c|}
\hline \multicolumn{2}{|c|}{ 成分指標 } & 個別 指標 \\
\hline \multirow[b]{2}{*}{ 生存指標 } & $\begin{array}{l}\text { ニードに関 } \\
\text { するもの }\end{array}$ & $\begin{array}{l}\text { 総人口当り児童人口比率 } \\
\text { 総人口当り就学前児童人口比率 } \\
\text { 総人口当り } 0 \text { 歳児人口比率 }\end{array}$ \\
\hline & $\begin{array}{l}\text { サービスに } \\
\text { 関するもの }\end{array}$ &  \\
\hline \multirow{2}{*}{ 健康指標 } & $\begin{array}{l}\text { ニードに関 } \\
\text { するもの }\end{array}$ & $\begin{array}{l}\text { 乳児死亡率 } \\
\text { 出生児数に対する低体重児比率 } \\
\text { 呪童 } 1,000 \text { 人当り療育医療給付件数 } \\
\text { 児童 } 1,000 \text { 人当り有成医療給付件数 }\end{array}$ \\
\hline & $\begin{array}{l}\text { サービスに } \\
\text { 関するもの }\end{array}$ & $\begin{array}{l}\text { 児童 } 1 \text { 万人当り児童遊園数（法によるもの） } \\
\text { 児童 } 1,000 \text { 人当り遊び場・広場数 } \\
\text { 乳児健康診查受診率 } \\
3 \text { 歳児健康診查受診率 }\end{array}$ \\
\hline \multirow{2}{*}{ 行動指標 } & $\begin{array}{l}\text { ニードに関 } \\
\text { するもの }\end{array}$ & （総人口当り児童人口比率） \\
\hline & $\begin{array}{l}\text { サービスに } \\
\text { 関するもの }\end{array}$ & $\begin{array}{l}\text { 児童 } 1 \text { 万人当り児童館数 } \\
\text { 児 } 1 \text { 万人当り教護院数 }\end{array}$ \\
\hline
\end{tabular}

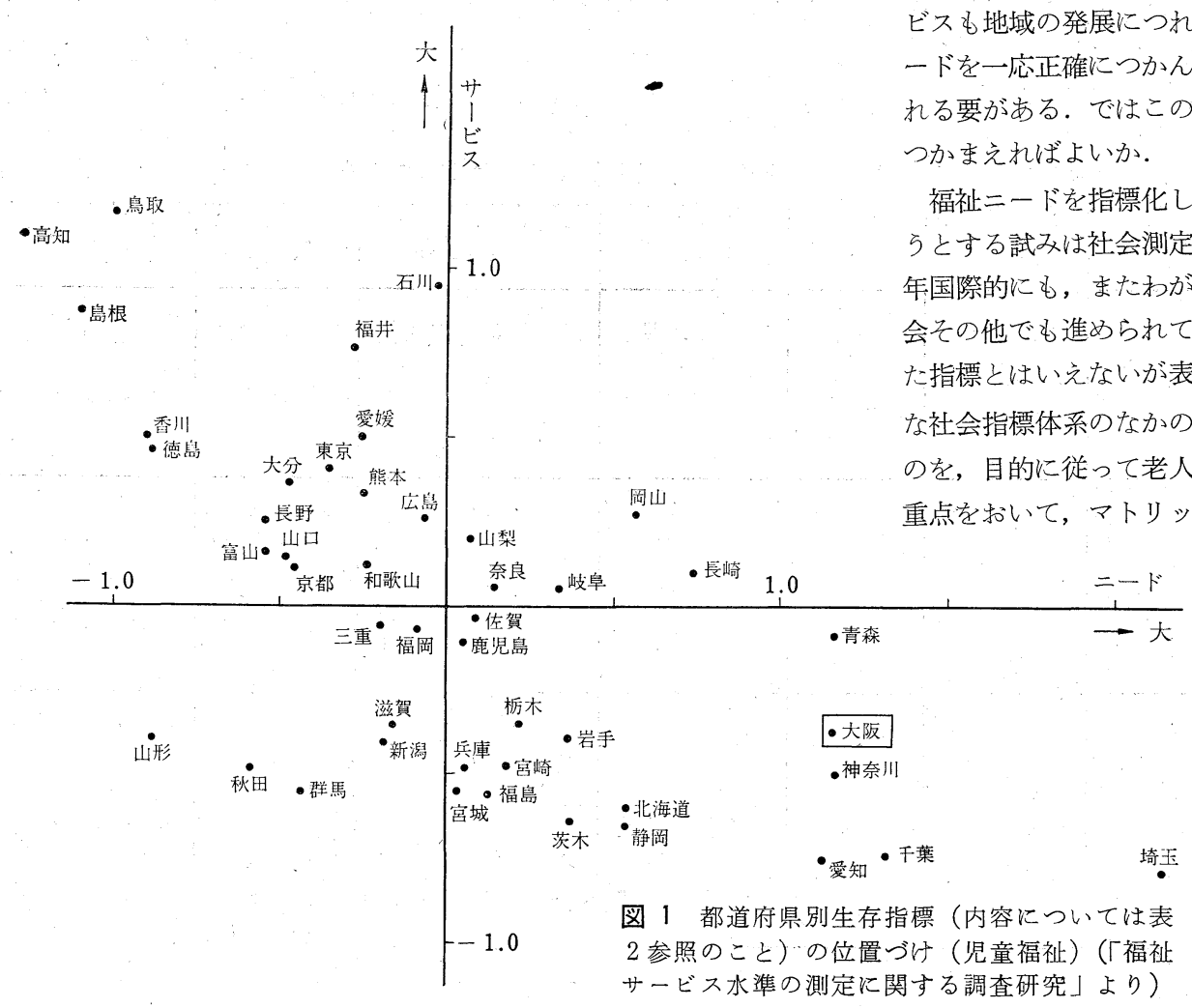

検討されつつあると聞く、リ八医学の担当 者としてあえて問題を提起するわけであ る.

福祉医療といら言葉は未だ定着したもの ではない，公費負担制度の対象となる医 療，とすれば医療に重点を置いた定義にな る。しかし医療の公費負担だけが福祉では ない，健康を伴わない福祉はもとより意味 がなかららが，そのために投資する財政を。 他に転用すれば，実質的に福祉サービスは はるかに向上するといらこともあるかもし れない。福祉医療施設というのはリハビリ テーション医療を包含した福祉施設という 程度に理解してもらってよいと思う。

\section{I. 地域開発と福祉医療}

地域開発計画と福祉医療は密接に関連し たものでなければなるまい。地域ごとの人 口構成や生産・住宅・教育等の環境を無視 した福祉サービスなどというものはあり光 ない. 安い土地が残っていたという理由で 都心から 1 日がかりの所に一大福祉センタ 一を建設する自治体が相次いだ。福祉步一 ビスも地域の発展につれて変動する福祉二 一ドを一応正確につかんだらえで組織化さ れる要がある。ではこの福祉ニードをどう

祉ニードを指標化し数量的に表現しよ らとする試みは社会測定の一分野として近 年国際的にも，末たかが国の国民生活審議 会その他でも進められている．標準化され 致1に示されるよう 福祉に関連したも や児童にそれぞれ

（「福祉サービス水準の測定に関する調查研究」より）

サービス水準の測定に関する調査研究」より） 




図 2 都道府県別健康指標の位置づけ（老人福祉）

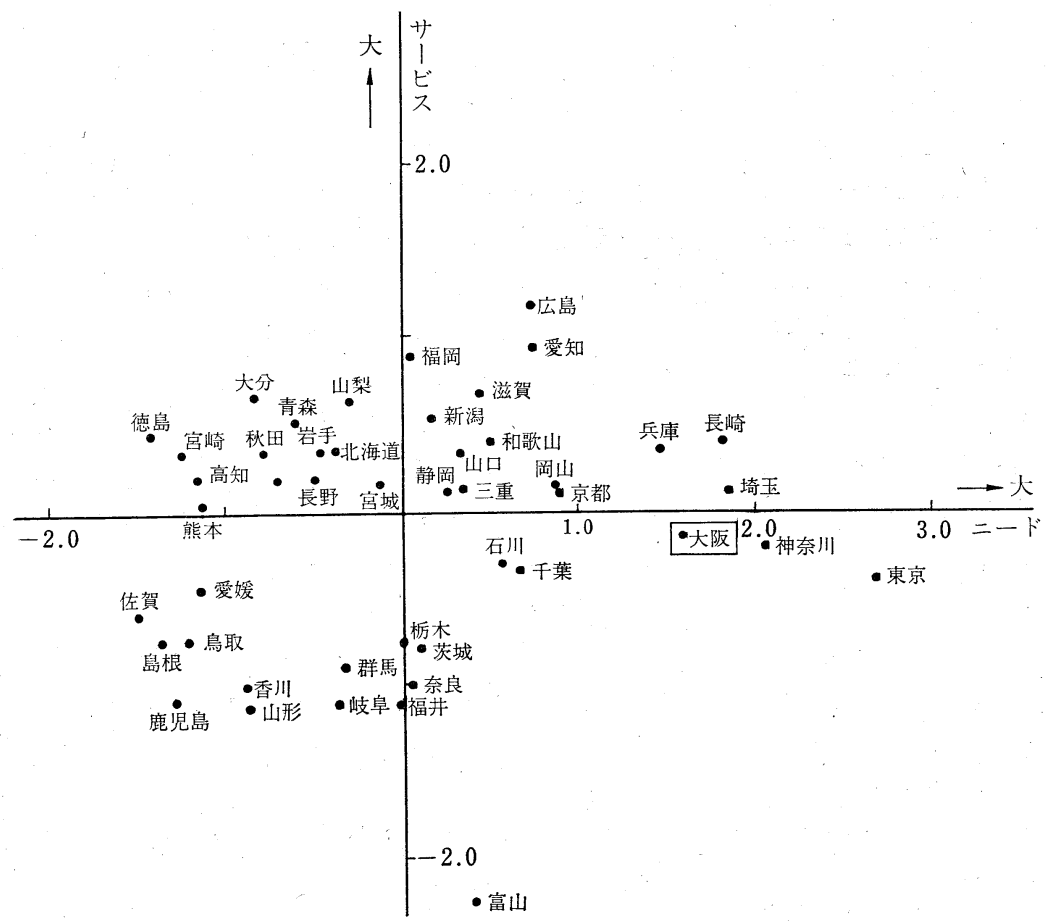

図 3 都道府県別労働指標の位置づけ（老人福祉）
般である.こうして選定さ れた各指標に関してたとえ ば表 2 の項目に示した数值 を算定し，さらに各指標毎 のウェイトをかけたものを 総計する。ただし算定に用 いられる個々の指標につい ては相関関係のない独立し たものを選び，ウェイトの つ方にも有識者による比 較法あるいは採点法その他 客観的な方法を採用する （実際には検定・標準化な ぞの統計的処理が注どこさ れるのであるが，詳細は参 考文献によられたい).

昭和 48 年に大阪府民生部 が地域開発研究所に依頼し た調查によればたとえば 児童福祉のなかでも生存指 標に関する結果は図 1 の如 くである。つ委り児童の保 育，それに関連した保母・ 施設・手当など生存と安全 に関するサービスはニード の高い割にサービス水準が 低いといらことになる。し かし健康指標をとりあげれ ば乳児死亡率, 幼児健康診 査, 育成医療給付などいず れも低いことを反映して低 ニード，低サービスに現状 はなっている。老人福祉の 万占健康指標 (図 2 ), 労働 指標（図3）はいずれも高 ニードと低サービスといら 福祉の遅れを如実に物語っ ている。ただし両者の指標 算定の基礎になる調査項目 が十分でないよらに思わ れ，今後の検討とより充実 した調查が望まれる.

福祉指標については測定 の精度, 信頼度を数理的に たかめる努力が必要である が一般的にその素資料とも 
表 3-1 各種リハビリテーションと関係省府庁局

\begin{tabular}{|c|c|c|c|c|}
\hline & 対象児者(物) & リハ・サービスの種類 & リハの職種 & 関係省府庁局 \\
\hline \multirow[t]{4}{*}{ 医学的リ八 } & $\begin{array}{l}\text { 肢体不自由(児)者 } \\
\text { リ公用器械器物 }\end{array}$ & $\begin{array}{l}\text { 各種リ八医療(更生・ } \\
\text { 育成医療を合む) } \\
\text { 器械器物の認可 }\end{array}$ & $\begin{array}{l}\text { 医師, 看護婦, OT, } \\
\mathrm{PT}, \mathrm{ST} \text {, 補装具士, } \\
\mathrm{MSW}, \mathrm{PSW}\end{array}$ & 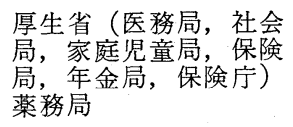 \\
\hline & 心身障害(児)者 & 同上 & 同上 & $\begin{array}{l}\text { 同上各局の他公衆衛生 } \\
\text { 局, 総理府 }\end{array}$ \\
\hline & 戦傷病者 & 同上 & 同上 & $\begin{array}{l}\text { 同上各局の他援護局, } \\
\text { 総理府 }\end{array}$ \\
\hline & 公害病患者 & 同上 & 同上 & $\begin{array}{l}\text { 環境衛生局, 医務局, } \\
\text { 社会局, 環境庁 }\end{array}$ \\
\hline 教育的リ八 & $\begin{array}{l}\text { 肢体不自由(者)児 } \\
\text { 心身障害(者)览 }\end{array}$ & $\begin{array}{l}\text { 再教育と養護教育と補 } \\
\text { 充教育 }\end{array}$ & 教育者グループ & 文部省 \\
\hline 職業的リ八 & $\begin{array}{l}\text { 肢体不自由者 } \\
\text { 戦傷病者 } \\
\text { 心身障害(児)者の一部 }\end{array}$ & 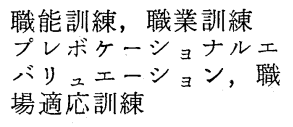 & $\begin{array}{l}\text { 職業指導員 } \\
\text { 職業カウンラー }\end{array}$ & 労働省, 厚生省 \\
\hline 心理的リ八 & $\begin{array}{l}\text { 肢体不自由(児)者 } \\
\text { 心身障害(児)者 }\end{array}$ & $\begin{array}{l}\text { ケースワーク, グルー } \\
\text { プワーク, カウンセリ } \\
\text { ング(社会児童, 職能 } \\
\text { 心理評価) }\end{array}$ & $\begin{array}{l}\text { 心理学者, SW, (保母, } \\
\text { 看護婦) }\end{array}$ & $\begin{array}{l}\text { 社会局, 家庭児童局 } \\
\text { 文部省, 労働省 }\end{array}$ \\
\hline 社会的リ八 & 肢体不自由児者 & $\begin{array}{l}\text { ケースワーク, グルー } \\
\text { プワーク, 社会生活指 } \\
\text { 導 }\end{array}$ & $\begin{array}{l}\text { 心理学者, SW, 福祉 } \\
\text { 司, 保母, 教師 }\end{array}$ & 同上 \\
\hline $\begin{array}{l}\text { スポーツ } \\
\text { レクリエ } \\
\text { レショ } \\
\text { ーシン }\end{array}$ & $\begin{array}{l}\text { 肢体不自由(児)者 } \\
\text { 心身障害(児)者 }\end{array}$ & $\begin{array}{l}\text { 身障スポーツ } \\
\text { 各種レクリエーション }\end{array}$ & $\begin{array}{l}\text { 体操士, SW, レクリ } \\
\text { エーシン専門職, 保 } \\
\text { 母, ナース, 教師 }\end{array}$ & $\begin{array}{l}\text { 社会局, 家庭児童局, } \\
\text { 文部省 }\end{array}$ \\
\hline
\end{tabular}

（橋倉による）

いらべき既存の統計資料は具体的な肉付けに欠けている といわざるを得ない。たとえば健康診查受診率だけで健 康を願らその地区住民のニードをどれだけ指標化し得た といえるだろう，労働・居住どれ一つをとってみてもそ の切実なニードをまごらかたなく表示してくれる資料が ほしいものである。施設の数や定員数だけでサービスの 水準が計れるわけがない，どのような内容で，どこにど れだけあるのかも問題になるだろら：足で調べずに役所 の控えをそのまま利用する単なる事例調査に終始して地 域全体の, 客観的評価を吝るといった欠宿は, このまま では一向改まらない，後に述べるようにこの種の基礎資 料を収集すること, ニードの切実さとサービスの効果を 具体的に正確につかまえることこそこれからの施設の一 大使命となるだろう. 地域開発と住民の福祉が切りはな せないものとすればそこには必ず鋭敏な耳と眼を持った 地域毎の福祉調查センターがあることになろう。

\section{II. 福祉医療施設の機能性}

「総合福祉相談センター」といら名称で呼ばれるよら に相談・判定・指導といら業務が，しか子乳幼児から老 人までを対象に, 総合されることが機能性に連るとい 5. 福祉のみならず医学的判定から治療までも総合しょ らといら考方方が強まり福祉医療施設といらぬえ的名称
が生まれたのであろら。総合は果して機能性を約束する だろらか。ここに宮城県総合福祉センターの例を紹介さ せていただこう。昭和43年 6 月 16 日の発足で, 従来の中 央児童相談所・精神薄弱者更生相談所・身体障害者更生 相談所・婦人相談所・精神衛生センター・中央優生保護 相談所を総合したものである. その後「総合福祉センタ 一一元化試案」が出されあるいは「総合福祉相談センタ 一法」の制定が企図されたといら。理由は，

1 ) 現在の総合福祉センターは各相談所の集りを総合 調整する仕組であるが，これでは各相談所が独立を認 められている以上; その運営にい打て当然, 定数・処 遇・予算・権限等に固執する傾向が強く調整が非常に 困難な状況にあり，このためセンタ一設立の目的を達 成できない現況にあること。

に始まって,

2 ）その他所属意識の非常に強いこと, 各相談所長の 主張が強く運営に円滑を欠くこと, 相談所の大小によ

り職員の俸給・手当などに差異のあること等々， 総合の上に改めて一元化策を押しすすめねばならない事 情が手にとるようである（いずれも大阪市調査資料よ り).

たしかに地域のあちこちに散在する諸施設を集中する ことは利用者にとって大変便利には相違ないが集中と統 
表 3-2 各府省が行なっている主要な身体障害者福祉行政

\begin{tabular}{|c|c|c|}
\hline 府 省 名 & 分 野 & 内 容 \\
\hline 総 理 府 & 総合調整 & 中央心身障害対策協議会 \\
\hline 大 蔵 省 & 税の減免 & $\begin{array}{l}\text { 所得税 } \\
\text { 所得控除 } \\
\text { 法人税 身体障害者授産事業使用する自動車等 } \\
\text { 関 身体障害者用に特に製作された器具等 }\end{array}$ \\
\hline 文 部 省 & 特殊教育 & 盲学校・ろら学校・養護学校 \\
\hline 厚 生 省 & 福祉一般年金・手当等 & $\begin{array}{l}\text { 身体障害(児)者福祉 } \\
\text { 戦傷病者戦没者遗族等の援護等 } \\
\text { 厚生年金保険・船員保険盖手当等 }\end{array}$ \\
\hline 運 輸 省 & 運賃割引 & 日本国有鉄道・私鉄バス等の運賃の割引 \\
\hline 郵 政 省 & 料金減免 & $\begin{array}{l}\text { NHKテレビ・ラジオ受信料の減免 } \\
\text { 点字郵便物等の無料扱い }\end{array}$ \\
\hline 労 働 省 & 雇用対策, 労働苂害 & 身体障害者雇用促進・身体障害者職業訓練校 - 労働災害補償保険 \\
\hline 建 設 省 & 公営住宅 & 身体障害者向け公営住宅 \\
\hline 自 治 省 & 税の減免 & $\begin{array}{l}\text { 住民税 所得控除 } \\
\text { 事業税 重度の障害者の行なうあんま・はり等医事に類する事業 } \\
\text { 自動車税・軽自動車税および自動車取得税 }\end{array}$ \\
\hline
\end{tabular}

（橋倉による）

合は別物である。ところでそもそもこうした sectionalism の生じる源は国の縦割り行政にあることはすでに常 識になっている．表 3 はそのよって来たる所以を明らか にするに十分であろら (橋含による). 国の行政の在り 方をそのままにして地方自治体だけで果して組織・機構 の一元化とそれによる施設の機能向上が可能力否か筆者 にはよく判らない，行政とは別にどのような部門があれ ば施設そのものとして機能的なのかといらことは次の III. で考察したい.

次にこの一カ所集中がその地域に和けるセンターとし ても果して機能的か否かの検討も必要となる. 利用者の 流れを考えた場合児童相談所から婦人相談所へいくこと はまずなからう。しかし身体障害者更生相談所には住宅 や結婚の相談空口があってほしいし，たとえば労働（職 業）サービスセンターや授産所が近接しておれば便利だ ろう。相談・判定・指導などの業務はできるだけ交通の 便利な地点に集中して営まれ, 地域によっては出先き機 関（サブセンター）や巡回相談バスを利用するのが一般 である．総合的な相談は市内で, 辺地では曜日をきめて 担当者が派遣されるという方式も多い。しかし, 現在の 悩みはそれぞれの福祉相談施設がどのあたりまでの地域 住民をどのような密度で cover しているかという資料に そしいことである．例を大阪にとってみよう，府立身体 障害者福祉センターは更生相談所, および付属病院を包 含するほかに労働省の職業訓練所, 文部省の養護学校, ろう学校, 盲学校も隣接しているなどかなり機能的な総 合施設であるが利用者の住区は必ずしも府下全域を均等 に cover するものではない。 また，東京都の調査によ
表 4 障害の種類別, 現職習得の方法

\begin{tabular}{|c|c|c|c|c|c|}
\hline 現職 & $\begin{array}{l}\begin{array}{l}\text { 障害の } \\
\text { 種類 }\end{array} \\
\end{array}$ & 視覚障害 & 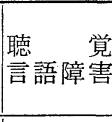 & 肢体障害 & 合 計 \\
\hline & $\begin{array}{l}\text { 前から現 } \\
\text { 并事 }\end{array}$ & $21.3 \%$ & $27.0 \%$ & $31.0 \%$ & $28.7 \%$ \\
\hline 受 & $\begin{array}{l}\text { 更生援護 } \\
\text { 施設 }\end{array}$ & 9.0 & 1.6 & 1.1 & 2.5 \\
\hline $\begin{array}{l}\text { 後 } \\
\text { 現 }\end{array}$ & $\begin{array}{l}\text { 公共職業 } \\
\text { 訓練所 }\end{array}$ & - & 0.8 & 2.1 & 1.5 \\
\hline $\begin{array}{l}\text { 職 } \\
\text { K }\end{array}$ & 特殊学校 & 32.0 & 5.7 & 1.7 & 7.6 \\
\hline 従 & 個人教授 & 13.1 & 12.3 & 13.3 & 13.1 \\
\hline 事 & その 他 & 24.6 & 52.5 & 50.8 & 46.6 \\
\hline & 計 & 100 & 100 & 100 & 100 \\
\hline
\end{tabular}

(京都市の調査による)

れば (安部, 東京都心身障害者福祉センター,による), 昭和44年度に来院した者のうち76名の就職者を調べると 職業訓練経験を有するのは 32 名/76に過ぎなかったとい ら. 京都市に拈ける身体障害者の実態調查の 結 果 (S. 44）も同様の事実を物語っている.すなわら障害の種類 別に現職習得の方法をみると表 4 の如く，いずれの障害 に関しても公的機関の職業教育が不十分であることが判 明する．資料がいささか古いこと，職業訓練の内容も問 題であることなどの批判もあろらが，この種の福祉施設 が地域住民のニードにどれだけ効果的に応じているかを 判定する一つの材料にはなろら. 更生医療や育成医療が 十分知られていない（利用者側にも，医療側にも）上 に，これを利用して多少とも障害を改善しうると勧告さ 
れても応じないまともな診察・医療相談をうけたこと のない障害者がいまだに跡をたたない，福祉活動は地域 （理）的にも，また時間的にも濃く・粘っこく続けられ ねばならない事実を痛感する。

\section{III. いわゆる全人格的リハビリテーションについて}

全人格的リハビリテーションといら表現もすでに耳新 しいものではなくなった。私どもが企画に参加した大阪 市立リハビリテーションセンターもその構想に「……教 育・労働等の関連分野との有機的連携により, 個々の障 害者に対して総合的で一貫性のあるリハビリテーション および援護のサービスを適切に提供し得る体制を整備し ……と唱っている. 具体的には，たと光ば相談・判定 部門では,

1 ）障害者の生活相談, 医療保健相談, 補装具相談, 施 設入所相談, 職業相談, 教育相談等に応じる.

2). 障害者のための適切な処遇方針を決定するため, 医 学的, 心理学的, 職業的, 社会的各専門分野にわたる 総合的判定を行ない障害者 1 人 1 人のリハビリテーシ ョンプログラムを作成する.

3 ）障害者の施設, 職場, または家庭における状況につ いて常に把握し関連機関との有機的連携のもとに必要 な措置を行なら。

杰た治療・訓練部門のほか、情報サービス部門・在宅少 一ビス部門（重度障害者の輸送サービスを含む）をおく ことになる。かりに文字通り実現されるとすればこれら の点は旧来の “更生指導所”にはなかったゆきとどいた サービスになるだろら．障害者にとってはばらばらの援 護施設を訪ねあぐねて遂に社会復帰の意欲すら失うとい らケースがたしかに少なくなかったであろう。新しい センターへ将ば，向うの方から，自分のあらゆる問題 を多面的総合的にとらえてくれるといら取り組み方は障 害者にとって画期的なものに相違ない, 一力所集中, 総 合化が問題をはらんでいることは既に指摘したと扮りで あるが，リハビリテーション本来の多面性を考えるなら ば，福祉業務としては総合される場所は不可欠である。 それと同時にこうして得られた障害者 1 人 1 人の包括的 な history こそ今後の福祉行政に最も役立つ基礎資料に なる.相談・判定・指導どれ一つをとってみても行政・ 職能・ケースワーク・医療の専門家の合同討議を必要と しその結果としてのプログラム作成 $\rightarrow$ 実施 $\rightarrow$ 跡づけ （follow up）へと進ま朴ばならないはずである. 専門家 の 1 人 1 人が抒そらく福祉法の不備・矛盾之行政の問題 点に行き悩むかと思われるが実はそれが法の改正なり施 策の前進につながるのではあるまいか。

ところで国立リハビリテーションセンター設置にあた
り次のような構想が研究調査会から打出された。「…... 国がその権威と財力とを集中し, 医学, 心理学, 社会 学; 工学等関連諸科学を総合的, 一元的に包括する専門 機関を設置して, リハビリテーションの研究開発の推進 之指導体制の確立を図る以外方途がない........上し， $\lceil\cdots \cdots . . .$. 地方の施設は, 身体障害者のニード, 社会的ニー ド等からタて，当分の間現状のままとし……」。れは “どういらことであろらか? 問題の在り方を地域の障害者 の中から汶みあげずに最先端（?）の諸科学を総合して 技術的にリハビリテーションを研究開発すればよい, 地 方の施設はその指導に甘んじてお扎といら風な響きがあ る: 国立 $\times \times$ 施設を設立して一方では国内的な指導を， 他方, 海外へ向けては進歩を誇示するモデルルームとす るのが明治以来のこの国の施策ではあった。しかしこの 種のモデル施設ができれば国の障害者福祉が充実するな どといらのはもはや幻想にしかすぎまい。

ことはリハビリテーションに限らない。福祉施策が障 害者の人格全般を取り上げようとするならば，障害者が 抢かれている現在の環境を多面的に正確に把握する努力 が先決かと思われる。われわ机は医療を介してしか障害 者を識らないわけであり, 福祉業務担当官はその業務の 関る範囲でしか障害を認識していまい，その地域に住む Aといら障害者のプロフィルを誰一人として正確につか んではいないのである。それを事情の許す限り克明に記 録し; その時々の福祉なり医療の及ぼす影響・効果を継 続して丹念に調べてファイルしていく地域の福祉調查セ ンターこそ全人格的福祉医療の基盤である，この基盤の 上にこそ障害者福祉の指導原理が生まれ育っていく.よ く抱き合わせにされているが，総合福祉センターの中に 医療施設は必須のものとは思えない。リ八医療の可能な 公的病院は少なくないし，そちらの方が障害者にとって 何かにつけて便利であろう．障害者専用の病院といらの が，先ず，括かしい，全人格的福祉あるいはリ八という ことですべての業務を集中設備する要は毛頭ない，研究 施設に関してはV．に触れる。

\section{IV. 施設としての重点事業}

福祉医療施設として必須の機能についてはすでに I . 〜III. に述べた.ここではそれらをも含めて最重要と思 われる業務をあげてみよう。重複を許されたい。

i ) 全人格的な相談・指導・判定

具体的には生活相談から医学判定まで大阪市のリ八セ ンターの説明であげた内容が含まれる．担当者は相談

・指導・判定の内容ごとに自治体の各部局から出向 し，医師は兼務でも可能であろう.

ii）総合的リハビリテーション 
地域のニードによって小児から老人まで包括される必 要があるかもしれないが，リ八活動は通常のPT・OT よりもむしろリ八後半の前職業的リ八や職業的リハに 重点を和くべきであるら。

iii）訪問サービス

ケースワーカー, ナース, リ八技術員, 医師が中心に なる。

iv）サブセンターとの提携

たと光ば老人福祉センター, 療育センター, 可能なら ば保健所などと提携しセンターとして機能する。

v）センターとしての機能

・i）， iii）の相談・指導・判定業務を通して得られた資 料の保管. プライバシーにわたることもあるので厳重 な注意を要するが，その上で先に述べたような福祉施 策の基礎資料に大い利用する．福祉医療に関する国 内外の情報も収集整備し利用者の用に供する.

・特定の地域を選んで福祉医療に関する野外調查

・福祉医療担当官, 訪問看護婦, ケースワーカー, ボラ ンティアなどの再教育, 医学生・PT・OT・STなど の実習の場にも利用される。養成, 再教育されたス夕 ッフをサブセンターへ派遣する。

・地域のボランティア活動（老人クラブ一障害児を守る 会……）との連携.これなしでは地域活動も，野外調 查子不可能に近い。

・医療施設，収容施設が包括される必要はない，障害者 の医療ニードに応じられない一般病院といらものがあ ろらはずがない，実際問題としては，たと学ば心身障 害者用のベッドを公的病院に幾床か設けるのでもよい はずである，収容施設はセンターときりはなして地域 計画の中で必要数作るべきである.

・重症心身障害者の輸送システム

・ 将来計画の立案

地域開発とあわせて福祉医療の将来をた学ず見つめて いる委員会を育てたい。もとより夢物語でなく, 上述 の現状調査に基づく着実なもので，たと壳ば経済不況 下の福祉医療なども予測しているべきであろら。

・広報活動

一方では福祉医療活動を周知徹底させ，他方，障害 者, 一般住民に主張する場を提供する.

\section{V. 福祉医療施設における研究面}

福祉医療施設に扣いても関連分野の研究が活発に進め られることはもとより望をしい。しかし大学医学部の研 究室分室にほかならない姿であったり研究者が施設職員 と交流なく, 研究成果が一向に施設へ還元されないのは なぜだろうか？一方では全国の平均的肢体不自由児施
設に見られるごとく研究のゆとりすらなくひたすら献身 の反要求される福祉医療施設も少なくない.

研究内容を調べても補装具の開発が圧倒的に多いのも 一驚である、福祉医療そのものの調查研究がなぜ育たな いのか？つまりI．に述べたようにどの種の福祉医療 ニードが高く，それにみあらサービスが低いか，どこへ ぞのように投資するのが最も経済的・効果的な福祉の在 り方なのか？.などといらテーマである. 老人医療の無 料化や乳幼児医療の無料化はこの検討を経て実施される べきであったろう．現在でも無料化に伴うメリットやこ の公費負担が老人の福祉に一番有効であったか否かの再 検討は必要なことである. 地域開発と福祉医療の在り方 なども重要なテーマとなるわけで，その中には当然環境 々障害者福祉の関係が論じられねばなるまい。自助具や 住居の問題は調度・衣服・食事などと共に「障害者の生 活科学」といらテーマに一括されよう、障害者をなくす ための研究は福祉医療施設だけでとらてい京かないきれ るものではないが，たえず生ま生ましいテーマを投げか け，障害者に関する包括的な資料がいつでも保管・整備 されてあれば貢献するところは大きい，具体的には大学 や各種研究所と共同してプロジェクトチームを組み，㐫 るいは委託研究にすればよい，現在の福祉関連諸法の総 検討と, 上り一貫したものにするための法的, 実務的, 行政的研究はどらしてもやらねばならないことではなか ろらか。たとえばリ八ビリテーション法としての一元化 がなければたとえ提唱されているよらなリハビリテーシ ョン局が厚生省に設けられても(その可能性は少ないが) 動けるはずもない

適職開発のため研究は老人や精神薄弱児（者）にとっ て意味するところが大きい，一般的に授産施設などの作 業種目も前近代的ではなかららか？ 経済界の不況にあ っても簡単につぶれない組織と職種など真剣探すべき だ。沢村がその報告で述べているように，収容授産施設 および福祉工場としての「太陽の家」は歴史に残る事業 であるが，新しい試みとして，数々の研究課題をもわれ わ机課している. 企業側の採算あるいは景気の変動を ぞのような機構で障害者の生産性と無理なく結合させれ ばよいのか？ どんな形の援護が障害者と同時に企業の 意欲を盛り上げるのか？ 最低賃金の保証か，年金制度 か？あるいはそれ以外のサービスか？等々である. ボランティア活動を計算にい玌ない福祉医療は今後, 成り立たないのではないか？日本だけがこの種の活動 の不毛の地だといら理由はない，大いに開発する方向へ 研究と㗢きか沙をつみ重ねたいものである。 


\section{VI. 福祉医療施設の将来}

肢体不自由児施設を例にとってみよう．脳性小児麻疸 の早期リハビリテーションが本格的に普及しだし, 年長 児放置例が影をひそめると共に，収容・教育・医療（整 形外科を中心とする）を主とする在来の肢体不自由児施 設へのニードは減ってくるものと思われる. 重度心身障 害児を除き地区の保育所を経て通常の小・中・高等学校 ないし養護学校へ進むだろら。いずれもが通学のための サービスはもとより, 教育と療育のために十分なスタッ フを当てている. 特別の事情でもない限り, 収容されて 教育を受けようという子供も，保護者もいなくなる．医 療サービスが必要とあれば地区の通園センターなり公的 病院にかよえばよい，公費負担の入院治療もゆきとどい ていて, 整形外科的治療しからけにくかった肢体不自由 児施設とは比べものにならない。一方の重度心身障害児 は在来の形の教育や整形外科的治療の対象とはなりにく い.したがって「メ×整肢園」へのニードは減る一方と なるだろら．少なくとも常勤の整形外科医を幾人も確保 する要は見当るまい．

上述の例は治療体系队教育施設の受け入れ体制の変革 なりが福祉医療施設の在り方を変えていくことを示して いる. 福祉医療施設はこうして時代と地域のニードに応 じて変容していくべき性格のものではあるまいか.だか らこそそのニードを適確に分析し掌握すると共に，積極 的な将来構想の打出せる体制が必要なわけである.

他方, 先に述べた(収容)授産施設や福祉工場とそれら を有機的に結びつける福祉医療施設はをすますそのニー ドが高まるものと考えられる.もとより一般企業への障 害者就業は大いに奨励されるべきであり, 雇用促進のた めのあらゆる手が打たれねばなるまいが，限界のあるこ とも確かである。一方では福祉工場なり授産施設の数と 種目を殖やし, 企業としての採算や安定性についても本 格的な取組みが急がれる.地域産業との結びつき以外に,
より広域的な企画・調整がなければ共倒れの危険さえ少 なくないだろう，各地域の福祉医療施設はそれぞれの職 域障害者に対して生活全般の援護サービスを提供するこ とによってできる限り収容を避け，地域社会に定着させ る努力を払らことにならう. 福祉工場群の生産活動を広 域的に企画・調整するといら作業, 職能の評価と訓練お よび適職の開発研究など医療面に劣らぬ重要な役割がこ れからの福祉医療施設にはあまた求められることである ら. 石油ショック以来, 役に立たなくなったプールだけ が自慢の施設は真剣にその将来像を考えてもらいたいも のである.

\section{参考文献（50音順）}

1）安部節子：心身障害者と職業，施設計画関係資 料集；103-116，大阪市民生局，昭46年より。

2）京都市社会福祉審議会：京都市身体障害者実態 調査結果，施設計画関係資料集；141-159，大 阪市民生局，昭46年より。

3）沢村誠志：ルポルタージュ“太陽の家”, 総合リ 八, $1 ;$ 915-921, 1973.

4）身体障害者職業リハビリテーション研究会：心 身障害者総合リハビリテーションセンターに打 ける職業リハビリテーションの基本的考光方, 大阪市民生局，昭 49 年.

5）地域開発研究所：福祉サービス水準の測定に関 する調査研究，大阪府民生部，昭 48 年.

6）橋倉一裕：肢体不自由者のリハビリテーション に括ける行政上の問題点, 総合リ八, $2 ; 7-13$, 1974.

7）星野貞一郎；児玉幹夫編：社会福祉調査, ミネ ルヴァ書房, 昭和 49 年.

8）宮城県民生部：宮城県総合福祉センター一元化 試案，施設計画関係資料集；71-94，大阪市民 生局, 昭 46 年より

9）リハビリテーション医療研究会: 大阪府立老人 総合センター構想の研究報告, 大阪府民生部, 昭和 49 年.

10）リハビリテーション研究調査会：国立リハビリ テーションセンター設置計画, 昭和 48 年.

\section{第 16 回日本義肢装具研究会}

\section{日 時：昭和50年11月15日（土曜日） \\ 会 場: 熊本市手取本町 8 熊本県福祉会館 TEL $0963-55-5241$}

演題募集：義肢装具に関するもの，400 字以内の抄録を 添えて 9 月 1 日までに下記宛郵送して下さ い.
第16回日本義肢装具研究会幹事 北川敏夫 熊本市本荘 1-1-1 熊本大学医学部整形外科 TEL 0963-63-1111（内線2695）

入会等の扮問い合わせは ₹162 東京都新宿区戸山町 43 東京都補装具研究所内 日本義肢装具研究会 事務局 加倉井周一あて

TEL 03-203-6141（内線 301 303） 